\title{
Brachyury Protein Antibody
}

National Cancer Institute

\section{Source}

National Cancer Institute. Brachyury Protein Antibody. NCI Thesaurus. Code C113840.

Any immunog lobulin that recognizes brachyury protein (protein T). 